\title{
Vasoplegic versus septic shock in cardiac surgery. Possibilities of differentiating between them and implementing appropriate therapy
}

\author{
Bartosz Kudliński ${ }^{1}$, Jakub Marczak ${ }^{1,2}$, Romuald Cichon $n^{1,3}$ \\ ${ }^{1}$ Medinet Heart Center Ltd. \\ ${ }^{2}$ Department of Cardiac Surgery, Wroclaw Medical University \\ ${ }^{3}$ Department of Cardiac Surgery, Chair, Medical University of Warsaw
}

Kardiochirurgia i Torakochirurgia Polska 2013; 10 (1): 14-19

\begin{abstract}
Among patients undergoing on-pump cardiac surgery (cardiopulmonary bypass - CPB), there is a population of patients who, shortly after the end of the procedure (and CPB), exhibit symptoms of generalized hypotension related to very low systemic vascular resistance, the treatment of which requires very large doses of vasoconstrictors. This clinical condition is known as vasodilatation or vasoplegic shock (a distributive shock). Risk factors of postoperative vasoplegia such as initial patient condition, preoperative pharmacotherapy, cardiac procedure type, extracorporeal perfusion, the activation of intrinsic mechanisms leading to vasodilatation, and infectious factors (complicating the previously "sterile" vasoplegia course) should be taken into consideration when planning the treatment and aiming to improve the postoperative outcome. Whether vasoplegia is of infectious or sterile etiology remains the big issue which dictates postoperative therapy: empirical antibiotic de-escalation therapy vs. standard perioperative antibiotic prophylaxis.
\end{abstract}

Key words: vasoplegia, septic shock, CPB, antibiotic prophylaxis.

The literature concerning vasoplegia after cardiac surgical procedures does not clearly define the problem of differentiating between vasoplegic and septic shock. The majority of authors define vasoplegic shock as a set of symptoms which require high doses of vasoconstrictors and are related to hypotension refractory to fluid therapy and to low systemic peripheral resistance, with a high cardiac index. The most common criteria are related to hemodynamic parameters:

\section{Streszczenie}

W kardiochirurgii z użyciem krążenia pozaustrojowego (cardiopulmonary bypass - CPB) obserwuje się populację pacjentów, u których w krótkim okresie po zakończeniu zabiegu (oraz CPB) występują objawy uogólnionej hipotensji związanej z bardzo niskim oporem obwodowym wymagającym zastosowania w terapii bardzo dużych dawek leków wazokonstrykcyjnych. Taki stan kliniczny określa się mianem wstrząsu wazodylatacyjnego lub wazoplegicznego (wstrząs dystrybucyjny). Istotnym problemem w leczeniu tego zespołu jest identyfikacja czynników ryzyka związanych z przedoperacyjnym stanem klinicznym pacjenta, prowadzoną terapią lekową, samym zabiegiem kardiochirurgicznym i jego rodzajem, prowadzeniem perfuzji w krążeniu pozaustrojowym, jak również aktywacją wewnątrzustrojowych mechanizmów powodujących wazodylatację oraz czynnikami infekcyjnymi wikłającymi „sterylny” przebieg wazoplegii. Odpowiedź na pytanie, czy jest to wstrząs wazodylatacyjny czy już wstrząs septyczny, implikuje wdrożenie adekwatnej terapii - empirycznej antybiotykoterapii deeskalacyjnej lub standardowej profilaktyki okołooperacyjnej.

Słowa kluczowe: wazoplegia, wstrząs septyczny, krążenie pozaustrojowe, antybiotykoterapia.

The mean arterial pressure (MAP) $<70 \mathrm{~mm} \mathrm{Hg}$, systemic vascular resistance index (SVRI) $<1400 \mathrm{dyn} / \mathrm{s} / \mathrm{cm}^{5} / \mathrm{m}^{2}$, systemic vascular resistance (SVR) $<400 \mathrm{dyn} / \mathrm{s} / \mathrm{cm}^{5}$; cardiac index (CI) $>2.5 \mathrm{l} / \mathrm{min} / \mathrm{m}^{2}$, central venous pressure (CVP) $>10 \mathrm{~mm} \mathrm{Hg}$, and time coincidence: the presence of clinical symptoms 2-12 $\mathrm{h}$ after the end of cardiopulmonary bypass (CPB) [1-4].

The mechanism for the occurrence of peripheral vasodilatation still remains unclear. The discussion on this topic stresses the significance of factors related to the pa-

Address for correspondence: Bartosz Kudliński, Dolnośląskie Centrum Chorób Serca MEDINET, ul. Chałubińskiego 7, 67-100 Nowa Sól, tel. +48502673 525, e-mail: bartoszkudlinski@gmail.com 
tient, medication, the cardiothoracic procedure and the correlated progress of extracorporeal circulation, and the activation of broadly understood inflammatory response [systemic inflammatory response syndrome (SIRS) and others] mediators, including insufficient arginine vasopressin secretion after CPB.

The following preoperative factors related to the patients and their medication should be noted: chronic use of vasodilators [angiotensin converting enzyme inhibitors (ACEI), calcium channel blockers, and amiodarone], preoperative intravenous heparin therapy, ejection fraction (EF) $<35 \%$, type II diabetes, and congestive heart failure [5-10]. It is these factors that result in the blockage of the influx of calcium ions into muscle cells by opening ATP-dependent potassium channels and hyperpolarizing myocytes. A similar effect can be caused by administrating amiodarone and phosphodiesterase III inhibitors postoperatively [9].

Another factor appears to be the disproportionately low level of arginine vasopressin secretion. Typically, CPB causes an increase in vasopressin concentration to $>100 \mathrm{pg} / \mathrm{ml}$, but in some vasoplegic patients its level was established at $<10 \mathrm{pg} / \mathrm{ml}$, which appears to be of primary significance for hypotension development $[11,12]$. For the most part, vasopressin acts vasoconstrictively via V1 receptors, which exert their effect by increasing the concentration of intracellular calcium. If the ATP-dependent $\mathrm{K}+$ channels are blocked, the flow of calcium is blocked and the actin-myosin interaction does not occur.

Chronic circulatory insufficiency, low left ventricular ejection fraction $<35 \%$, type II diabetes, and chronic renal failure constitute independent risk factors for the development of vasoplegic shock, which is related both to the treatment employed in these clinical situations and to the chronic metabolism disorder of the endothelium and myocardium - the prolonged activation of renin-angiotensin-aldosterone system (RAAS) and proinflammatory mediators (especially in obese patients due to high levels of proinflammatory cytokines in fat tissue) [13], the propensity for apoptosis of endothelial tissue, and the down-regulation of beta-adrenergic receptors.

Cardiac surgery also constitutes an independent risk factor for vasoplegia. Most studies focus on aorto-coronary bypass surgery; however, the aforementioned risk factors occur much more often and at a higher intensity in patients with valvular defects, patients requiring mechanical cardiac support, and those undergoing urgent procedures [14].

The primary risk element related to cardiac surgery is CPB - its duration, the employed oxygenator and drain types, priming, myocardial protection, drugs administered during CPB (heparin/protamine), and, most importantly, perfusion pressure.

The contact between the patient's blood and the drain system, tissue ischemia, and reperfusion injury result in the development of a systemic inflammatory response with the activation of inflammatory mediators and subsequent inducible nitric oxide synthetase (iNOs) stimulation [iNOs - intracellular cyclic guanosine monophosphate (cGMP) ac- tivation]. The consequences of this include cytokine storm and vasodilatation refractory to vasoconstrictors with reduced myocardial contractility and increased endothelial permeability [15-17].

Other causative factors such as injury, blood loss, burns, hypothermia, and, particularly, infection result in a practically identical simulation of the cytokine configuration and in related clinical consequences, including multi-organ failure.

The difference is that the end of exposure (CPB) to the causative factor enables the extinguishing of the "fire" and idiopathic microcirculation stabilization. This occurs in most "benign" forms of post-CPB vasoplegia [18].

It is important to note the occurrence of vasoplegia in procedures that do not employ extracorporeal circulation (off-pump), in which the activation of pro-inflammatory cytokines and iNOs appears to be initiated by heparin-protamine administration with all the consequences of the development of SIRS and multi-organ failure due to hypotension refractory to catecholamines [1].

The incidence of vasoplegia is estimated at $8.8-10 \%$ for patients undergoing CPB procedures, but for those with severe preoperative left ventricular dysfunction it may reach $42 \%$. Mortality for the severe forms of vasoplegic shock reaches $25 \%$ in spite of employing adequate treatment $[1,15,17]$.

If the diagnostic criteria for vasoplegic shock are met after cardiac surgery, it is vital to consider appropriate directions of therapy:

1. Adequate fluid therapy.

2. Hemodynamic monitoring assessing the reaction to fluid therapy and monitoring the administration of vasoconstrictor agents.

3. "Causative" treatment for vasoplegia: SIRS - extracorporeal therapies.

4. Treatment with vasoconstrictor agents.

5. Differential diagnostics between vasoplegia and septic shock due to probable infection with the introduction of antibiotic de-escalation therapy.

6. Prophylaxis in the case of patients from the deep vasoplegia risk group.

The concept of adequate fluid therapy is difficult to define for any kind of shock. This is particularly true of distributive shocks, to which group the post-CPB vasoplegic shock belongs. There is no objective method of assessing the patient's volemia and fluid demand. The hemodynamic monitoring technologies that are available in the medical market (transpulmonary thermodilution and heart rate curve analysis) enable the evaluation of the patient's amenability to fluid therapy. Static parameters such as CVP, pulmonary capillary wedge pressure (PCWP), or reversed end-diastolic velocity (REDV) do not correlate with the assessment of volemia [18], while dynamic parameters (pulse pressure variation (PPV), systolic pressure variation (SPV), stroke volume variation (SVV)] are governed by strict methodological limitations. Possible alternatives appear to include fluid therapy based on extravascular lung water (EVLW) evaluation or identifying fluid susceptibility based on the position on the Frank-Starling curve (Fig. 1, 2). 


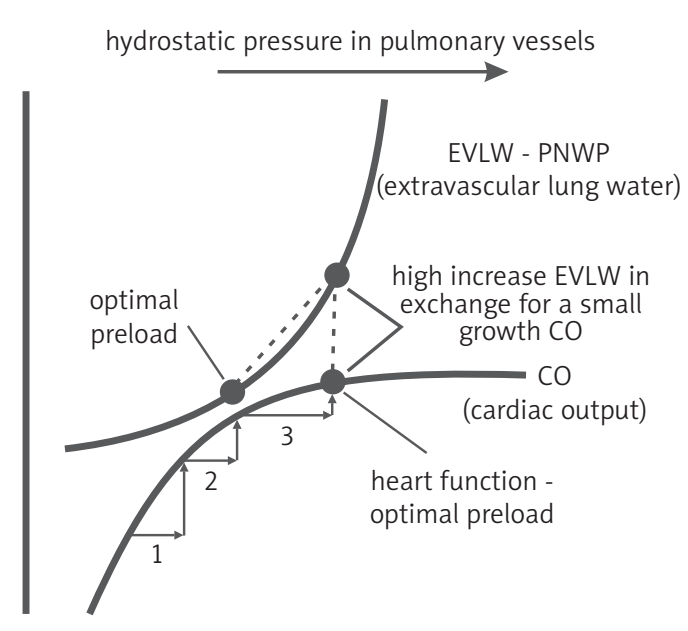

Fig. 1. Addopted from: Marik et al. Annals of Intensive Care 2011

Adequate fluid therapy is aimed at providing the system with the "shocked" circumferential bed tension with the fluid volume required for maintaining tissue flow while avoiding overhydration with all its negative consequences. Hemodynamic monitoring in the case of vasoplegic shock should be tailored to the available technology and the experience of the treatment team. Monitoring oxygen delivery $\left(\mathrm{DO}_{2}\right)$ and oxygen consumption $\left(\mathrm{VO}_{2}\right)$ relationships and maintaining adequate tissue blood flow in microcirculation is crucial. Employing a catheter in the pulmonary artery is a gold standard in cardiac anesthesiology, especially if it is possible to constantly monitor cardiac output and mixed venous oxygen saturation (Swan-Ganz Combo V, Edwards Lifesciences). In turn, transpulmonary thermodilution technologies (PICCO Pulsion, EV1000 Edwards Lifesciences) are irreplaceable when it comes to EVLW evaluation and acute lung injury/acute respiratory distress syndrome (ALI/ ARDS) differentiation. However, vasoplegic shock is a microcirculation disorder and macrocirculatory hemodynamic parameters, without regard for organ perfusion, are insufficient for conducting adequate therapy. At the current state of knowledge, monitoring tissue blood flow entails the measurement of such parameters as lactate levels, pH, and alkali deficiency, tissue tonometry, tissue oxygenation [near infrared reflectance spectroscopy (NIRS) technology], and tissue oxygen saturation $\left(\mathrm{StO}_{2}\right)$ [19]. The acquired information enables the coordination of the following chain of components: fluid therapy and vasoactive treatment at the tissue level.

Causative treatment of vasoplegic shock in the course of CPB includes the elimination of factors predisposing to inflammatory mediator activation. Introducing modern technologies related to biocompatible materials, out of which the CPB system components are constructed, as well as technologies based on the concept of existing mediator removal, blazes a trail for leading scientific studies. Employing a whole gamut of extracorporeal inflammatory mediator removal techniques based on filtration-absorption technologies [from continuous veno-venous hemofiltration (CVVH) to coupled plasma filtration adsorption (CPFA)] has not

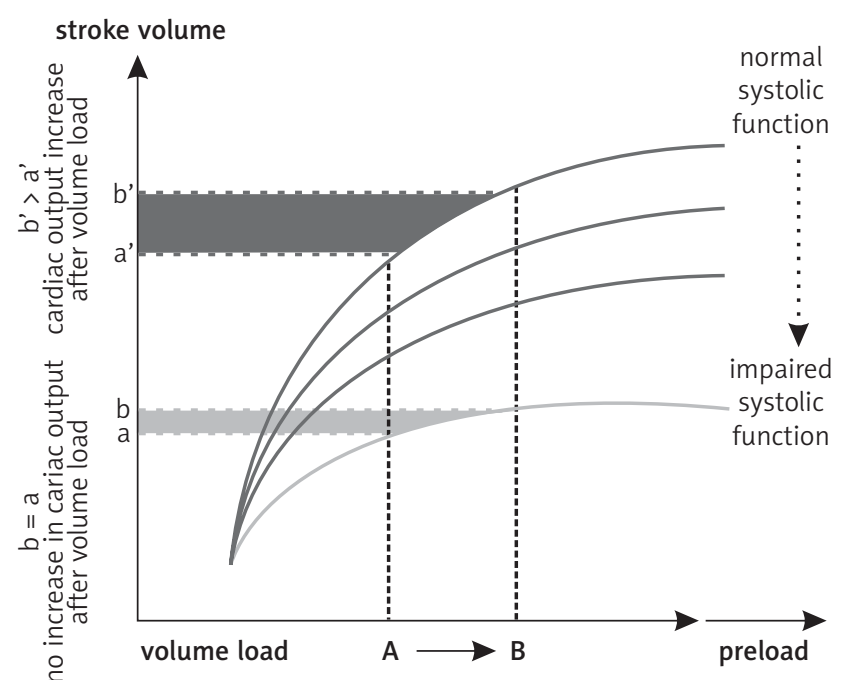

Fig. 2. Addopted from: Marik et al. Annals of Intensive Care 2011

yet yielded convincing data concerning the improvement of clinical results. It appears that the problem is related to the type of the filter, which should have both anticoagulative (heparin coating) and absorptive capabilities, in order to ensure the precise removal of specific pro-inflammatory mediators, while sparing the anti-inflammatory mediators and other systemic proteins. Examples of this include a group of studies from Japan in which polymyxin B and its modifications were used to remove pro-inflammatory mediators and lipopolysaccharide (LPS) in patients in septic shock [20] and the works by Honoré employing the oXiris filter [21]. Notwithstanding the above, there are still no convincing reports concerning extracorporeal therapy for postCPB vasoplegia.

Therapy with vasoactive drugs may also be considered a "causative" treatment for vasoplegic shock; in addition to the standard use of noradrenaline, it employs vasopressin and methylene blue. Early goal directed therapy (EGDT) in post-CPB vasoplegia therapy pertains to the values of MAP $>70 \mathrm{~mm} \mathrm{Hg}$ and SVR $>800 \mathrm{dyn} / \mathrm{s} / \mathrm{cm}^{5}$. These levels can be reached by administering $0.01-0.4 \mathrm{\mu g} / \mathrm{kg} / \mathrm{min}$ of noradrenaline or by including vasopressin in the therapy and using the fact that, dosed at 0.01-0.1 U/min, it acts on the V1 receptor, while taking into consideration its adverse drug reactions (constriction of skin and visceral vessels) [22, 23]. The receptor V1 analogue terlipressin is used in a similar manner, dosed at $1 \mu \mathrm{g} / \mathrm{kg} / \mathrm{h}$ [24]. The described therapy appears to be safe and does not cause disturbances of organ blood flow, particularly within the CNS, viscera, and kidneys. Nor does it disturb the metabolic parameters - lactates, $\mathrm{pH}$, and $\mathrm{BE}$. Acting on the $\mathrm{V} 2$ receptor results in fluid stabilization of the organism and diuresis. In a group of patients who were preoperatively administered ACE inhibitors and had significantly lowered EF, an infusion of a small dose of vasopressin $(0.03 \mathrm{U} / \mathrm{min})$ during CPB and during the 4 hours after coronary artery bypass surgery (CABG) is safe and advantageous. It clearly reduces the required doses of vasopressors, enhances the hemodynamic profile, increas- 
es diuresis and reduces blood loss during the first $24 \mathrm{~h}$ after the operation. Its effect on the kidneys is also significant, as it results in vasoconstriction of the efferent arteriole, as opposed to other vasopressors acting on the afferent arterioles and reducing GFR (glomerular filtration rate) and UO (urine output). It exerts a similar protective effect on the CNS and the coronary vessels [25].

Using methylene blue in treating post-CPB vasoplegia has a well-grounded position in modern intensive cardiosurgical therapy. Methylene blue is a drug that directly inhibits the production of nitric oxide (iNOs) and blocks cGMP, which enables the restart of the mechanism related to CAMP and ATP via dependent potassium channels, therefore enabling the normalization of cellular calcium metabolism and the regaining of the physiological properties of myocytes [15]. Methylene blue is not a directly vasoconstrictive drug, as it does not constrict the vessels when vasoplegia is not present (in the absence of iNOs activation and NO - cGMP excess). The action of methylene blue dosed at $2 \mathrm{mg} / \mathrm{kg}$ body weight (bw) in a $20 \mathrm{ml}$ bolus is safe and requires subsequent continuation in continuous infusion up to the dose of $10 \mathrm{mg} / \mathrm{kg}$ bw. Reports suggest that exceeding the dose of $>40 \mathrm{mg} / \mathrm{kg}$ bw can be hazardous and related to hemolysis, hyperbilirubinemia, and excessive visceral vasoconstriction [25].

There are reports stressing the significance of the timing of methylene blue administration. Clinical situations have been observed in which the infusion of the drug did not reduce vasoplegia. A probable explanation for this seems to be the action of cGMP, which, after initial significant expression, is clearly reduced due to substantial overproduction of NO and the change in the metabolism of intracellular transmitters. Thus, a therapeutic window develops, during which methylene blue is ineffective. In experimental studies on animals, this time period lasts several hours, and the increasing presence of cGMP enables the return of methylene blue sensitivity and the slow reduction of vasoplegia symptoms [26]. A similar effect, with varying time window length, has been observed in humans [27-29]. Methylene blue is also employed in the treatment of anaphylactic shock. The cardiac surgery literature describes cases in which methylene blue was employed in the anaphylactic reaction to protamine [30].

If a shock with low peripheral resistance occurs after cardiac surgery, it is clinically significant to ask whether it is a distributive shock related to non-infectious activation of mediators and iNOs or a septic shock with infectious etiology.

Septic shock in cardiac surgery may be associated with the patient's preoperative clinical condition: infective endocarditis, latent infectious foci; intraoperative pathology - endotoxemia due to visceral blood flow disorders and bacterial translocation during CPB; or, finally, situations in which vasoplegia refractory to medical treatment is complicated by an infection and develops, more or less noticeably, into septic shock.

The key point of this differentiation is the decision to employ adequate antibiotic therapy. According to numer- ous scientific reports accumulated in the Surviving Sepsis Campaign guidelines, empirical antibiotic de-escalation therapy should be implemented as soon as possible (1 hour) after the diagnosis/suspicion of septic shock. Delaying this intervention results in an increase in mortality by $10 \%$ for each subsequent hour [31].

At the present time, the only proven marker which allows for an attempt to differentiate between aseptic vasoplegic shock after CPB and an infection causing the development of septic shock is the marking of the level of procalcitonin (PCT).

Procalcitonin is also an acute-phase protein and an inflammatory response mediator; therefore its level increases during the course of uncomplicated cardiac surgery employing extracorporeal circulation. Numerous studies have confirmed that the peak concentration of PCT occurs during the first 24 postoperative hours and normalizes within approximately one week [32]. In patients with an infection, the PCT level was markedly higher and increased more rapidly within the $24 \mathrm{~h}$ period than in the cases of "aseptic" SIRS.

During an uncomplicated treatment course in CPB patients, PCT varies within the range of $0.41 \pm 0.36 \mathrm{ng} / \mathrm{ml}$, with the peak occurring during the first day after the operation, and normalization taking place within 3-4 days. In the case of patients with infection (confirmed microbiologically), one can distinguish patients with septic shock (PCT 96.98 $\pm 119.61 \mathrm{ng} / \mathrm{ml}$ and rapid accretion rate) and patients with limited infection (pneumonia, mediastinitis, bacteremia) with an indirect PCT level of $4.85 \pm 3.31 \mathrm{ng} / \mathrm{ml}$. A group of patients who received targeted antibiotic therapy in case of infection has also been identified. The PCT level in this group did not exceed $<1 \mathrm{ng} / \mathrm{ml}$. The best cutoff point for the diagnosis of bacterial/fungal infection is the PCT level of $1 \mathrm{ng} / \mathrm{ml}$ (sensitivity $85 \%$, specificity $95 \%$ ). In the case of vasoplegic (cardiogenic) shock, the cutoff is at the level of $10 \mathrm{ng} / \mathrm{ml}$ (96.98 \pm 119.61 vs. $11.30 \pm 12.3 \mathrm{ng} / \mathrm{ml}$, sensitivity $100 \%$, specificity $62 \%$ ) [37]. In all the presented patient groups, the CRP level was elevated and, during the first postoperative days, did not exhibit a significant correlation with the presence of infection or the risk of septic shock development.

Below, we present two case studies, which we have observed in our clinical practice.

\section{Case study 1}

A 77-year-old patient was admitted for a planned CABG procedure. Medical history was typical for ischemic heart disease (IHD), without significant details. The surgical procedure included the implantation of 3 venous bypasses and 1 arterial bypass. The duration of the CPB was $45 \mathrm{~min}$; perfusion pressure: $60-80 \mathrm{~mm} \mathrm{Hg}, \mathrm{Cl}: 2.4 \mathrm{l} / \mathrm{min} / \mathrm{m}^{2}$. Circulation was terminated uneventfully. Intraoperative laboratory examinations, circulatory system monitoring, diuresis, and ventilation were normal.

In the ICU, the patient was stable for 2 hours: minor drainage, good diuresis, stable circulation. Approximately 2 hours after the end of the CPB, a BP drop was observed, as well as tachycardia > 160/min, saturation drop, $\mathrm{pH}$ 7.1, 
BE (-12), hemoglobin (HB) 10.6, hematocrit (Hct) 26\%, platelet count (PLT) 118, oliguria, activated partial thromboplastin time (APTT) $70 \mathrm{~s}$.

Due to the suspicion of bleeding, transthoracic echocardiogram (TTE) was performed - no signs of tamponade or pleural effusion. Intensive fluid therapy was implemented, and vasopressor agents were infused: noradrenaline (0.01$0.3 \mu \mathrm{g} / \mathrm{kg} / \mathrm{min})$, dobutamine $(10 \mu \mathrm{g} / \mathrm{kg} / \mathrm{min})$. Two units of packed red blood cells (PRBC) and 2 units of fresh frozen plasma (FFP) were transfused, and $\mathrm{Co} / \mathrm{Cl}$ monitoring was employed (FloTrac, Edwards Lifesciences). As the therapy was ineffective, an intra-aortic balloon pump (IABP) was used, and adrenaline infusion (0.01-0.08 $\mu \mathrm{g} / \mathrm{kg} / \mathrm{min})$ was included in the therapy.

In the $10^{\text {th }}$ hour after the occurrence of the symptoms, hemodynamic monitoring was extended to include the pulmonary artery catheter (PAC): CO > $15 \mathrm{l} / \mathrm{min}, \mathrm{SV} 80 \mathrm{ml}$, PVR $20 \mathrm{~mm} \mathrm{Hg}$, PCWP $16 \mathrm{~mm} \mathrm{Hg}$, SVR $146 \mathrm{dyn} / \mathrm{s} / \mathrm{cm}^{5}$. Anuria. Laboratory examination: lactates $12 \mathrm{mmol} / \mathrm{l}, \mathrm{pH}$ 6.9, BE (-20), white blood cells (WBC) $36 \mathrm{~K} / \mu \mathrm{l}$, PLT $56 \mathrm{~K} / \mu \mathrm{l}, \mathrm{Hb}$ $7.9 \mathrm{~g} \%$, CRP > $50 \mathrm{mg} / \mathrm{dl}, \mathrm{PCT}>100 \mathrm{ng} / \mathrm{ml}$. Deep vasoplegia was diagnosed, and, due to the very high level of PCT, septic shock was diagnosed as well.

Because of this, empirical antibiotic de-escalation therapy was employed (meropenem + vancomycin) as well as high-volume continuous veno-venous hemofiltration (CVVHF) - 4 hourly pulses $80 \mathrm{ml} / \mathrm{kg} / \mathrm{h}$ each, 2 system replacements (Aquarius, Baxter) within $24 \mathrm{~h}$. Fluid therapy and vasoconstrictor administration was conducted under PAC control. Vasopressin and methylene blue were not used in the treatment due to their shortage in the ICU.

In spite of this, during the next $24 \mathrm{~h}$, vasopressor infusion was gradually reduced, as the treatment team observed the gradual normalization of laboratory parameters and the return of diuresis. During the $3^{\text {rd }}$ day, mechanical ventilation was discontinued, while during the 5th day, CVVHF and vasopressor therapy were terminated.

On the $6^{\text {th }}$ day, the patient was transferred to the cardiac surgery department for further treatment. The numerous cultures collected throughout the hospitalization yielded no microbiological identification of the pathogen responsible for the infection. The PCT level was normalized on the $8^{\text {th }}$ day after the CPB.

\section{Case study 2}

The patient (aged 76, with a history of unstable IHD, chronic renal failure and circulatory insufficiency, after large intestine resection due to cancer) was qualified for an urgent $C A B G$ procedure due to critical constrictions in the left main coronary artery (LMCA), left anterior descending artery (LAD), left circumflex artery (LCX), first marginal (M1), and right coronary artery (RCA). EF was $25-30 \%$.

The duration of the CPB was 100 min. Hemofiltration was used during the procedure. Full arterial revascularization was required, as the venous vessels were found to be inadequate for grafting. The patient required small doses of vasopressors (noradrenaline and dobutamine) already after the start of surgery. PAC - relative hemodynamic stabilization after CBP, SVR $400 \mathrm{dyn} / \mathrm{s} / \mathrm{cm}^{5}$.

Approximately $60 \mathrm{~min}$ after the end of surgery, substantial vasoplegia was quickly corrected by means of fluid therapy and vasopressors (adrenaline, noradrenaline, dobutamine). Despite great effort, the IABP was impossible to implement due to generalized atherosclerosis. Relative circulatory stabilization and return of diuresis - approx. $2 \mathrm{ml} / \mathrm{kg} / \mathrm{h}$.

In the $8^{\text {th }}$ hour after the CPB, the patient's condition worsened again rapidly, as inflammatory parameters increased markedly: PCT $>75 \mathrm{ng} / \mathrm{ml}, \mathrm{CRP}>50 \mathrm{mg} / \mathrm{dl}, \mathrm{WBC}$ $36 \mathrm{~K} / \mu \mathrm{l}$. PAC - SVR $130 \mathrm{dyn} / \mathrm{s} / \mathrm{cm}^{5}$. Empirical antibiotic de-escalation therapy was employed (carbapenem + glycopeptide), as well as intensive fluid therapy under PAC control (transpulmonary thermodilution was impossible to implement). Within $24 \mathrm{~h}$, diuresis returned, the hemodynamics stabilized, and vasoconstrictor agent infusion was reduced.

In sum, during $24 \mathrm{~h}$ after the $\mathrm{CPB}$, the patient received 16 I of fluids, including 8 u PRBC and 6 u FFP. He did not require CRRT, and the total drainage did not exceed $2000 \mathrm{ml}$.

\section{Conclusions}

Treating vasoplegic shock after cardiac surgery entails identifying the patients at risk, based on the following factors: chronic ACEI use, calcium channel blockers, continuous infusion of heparin, beta-blockers, amiodarone and phosphodiesterase III inhibitors, severe left ventricular failure, EF $<25-30 \%$, type II diabetes, and renal failure.

Efficacious vasoplegia prophylaxis is possible by means of vasopressin or methylene blue infusion.

Treatment requires a combination of actions including adequate fluid therapy and vasoconstrictor therapy under the control of invasive hemodynamic monitoring: PAC, transpulmonary thermodilution, heart rate curve analysis.

Extracorporeal blood-cleansing technologies require further clinical studies in order to confirm or deny their efficacy.

Procalcitonin is an efficient marker differentiating vasoplegic shock from infection and septic shock, and it enables quick implementation of antibiotic de-escalation therapy, which is decisive for prognosis.

\section{References}

1. Sun X, Zhang L, Hill PC, Lowery R, Lee AT, Molyneaux RE, Corso PJ, Boyce $\mathrm{SW}$. Is Is incidence of postoperative vasoplegic syndrome different between off-pump and on-pump coronary artery bypass grafting surgery? Eur J Cardiothorac Surg 2008; 34: 820-825.

2. Argenziano M, Chen JM, Choudhri AF, Cullinane S, Garfein E, Weinberg AD, Smith CR Jr, Rose EA, Landry DW, Oz MC. Management of vasodilatory shock after cardiac surgery: identification of predisposing factors and use of a novel pressor agent. J Thorac Cardiovasc Surg 1998; 116: 973-980.

3. Carrel T, Englberger L, Mohacsi P, Neidhart P, Schmidli J. Low systemic vascular resistance after cardiopulmonary bypass: incidence, etiology, and clinical importance. Card Surg 2000; 15: 347-353.

4. Landry DW, Oliver JA. The pathogenesis of vasodilatory shock. N Engl J Med 2001; 345: 588-595.

5. Gomes WJ, Carvalho AC, Palma JH, Teles CA, Branco JN, Silas MG, Buffolo E. Vasoplegic syndrome after open heart surgery. J Cardiovasc Surg (Torino) 1998; 39: 619-623. 
6. Mekontso-Dessap A, Houel R, Soustelle C, Kirsch M, Thebert D, Loisance DY. Risk factors for post-cardiopulmonary bypass vasoplegia in patients with preserved left ventricular function. Ann Thorac Surg 2001; 71: 1428-1432.

7. Byrne JG, Leacche M, Paul S, Mihaljevic T, Rawn JD, Shernan SK, Mudge GH, Stevenson LW. Risk factors and outcomes for ,vasoplegia syndrome' following cardiac transplantation. Eur J Cardiothorac Surg 2004; 25: 327-332.

8. Tuman KJ, McCarthy RJ, O'Connor CJ, Holm WE, Ivankovich AD. Angiotensinconverting enzyme inhibitors increase vasoconstrictor requirements after cardiopulmonary bypass. Anesth Analg 1995; 80: 473-479.

9. Mets B, Michler RE, Delphin ED, Oz MC, Landry DW. Refractory vasodilation after cardiopulmonary bypass for heart transplantation in recipients on combined amiodarone and angiotensin-converting enzyme inhibitor therapy: a role for vasopressin administration. J Cardiothorac Vasc Anesth 1998; 12: 326-329.

10. Shieh JP, Chu CC, Chen JY, Chen YH, Yeh FC, Hsing CH. Acute fatal vasoplegia and asystole induced by intravenous amiodarone after cardiopulmonary bypass in a patient with preoperative cardiogenic shock. Acta Anaesthesiol Sin 1999; 37: 205-210.

11. Tayama E, Ueda T, Shojima T, Akasu K, Oda T, Fukunaga S, Akashi H, Aoyagi S. Arginine vasopressin is an ideal drug after cardiac surgery for the management of low systemic vascular resistant hypotension concomitant with pulmonary hypertension. Interact Cardiovasc Thorac Surg 2007; 6: 715-719.

12. Treschan TA, Peters J. The vasopressin system: physiology and clinical strategies. Anesthesiology 2006; 105: 599-612.

13. Esposito K, Pontillo A, Di Palo C, Giugliano G, Masella M, Marfella R, Giugliano D. Effect of weight loss and lifestyle changes on vascular inflammatory markers in obese women: a randomized trial. JAMA 2003; 289: 1799-1804.

14. Rastan AJ, Eckenstein JI, Hentschel B, Funkat AK, Gummert JF, Doll N, Walther T, Falk V, Mohr FW. Emergency coronary artery bypass graft surgery for acute coronary syndrome: beating heart versus conventional cardioplegic cardiac arrest strategies. Circulation 2006; 114 (1 Suppl): 1477-1485.

15. Evora PR, Ribeiro PJ, Vicente WV, Reis CL, Rodrigues AJ, Menardi AC, Alves Junior L, Evora PM, Bassetto S. Methylene blue for vasoplegic syndrome treatment in heart surgery: fifteen years of questions, answers, doubts and certainties. Rev Bras Cir Cardiovasc 2009; 24: 279-288

16. Balligand JL, Cannon PJ. Nitric oxide synthases and cardiac muscle. Autocrine and paracrine influences. Arterioscler Thromb Vasc Biol 1997; 17: 1846-1858.

17. Bragadottir G, Redfors B, Nygren A, Sellgren J, Ricksten SE. Low-dose vasopressin increases glomerular filtration rate, but impairs renal oxygenation in post-cardiac surgery patients. Acta Anesthesiol Scand 2009; 53: 1052-1059.

18. Marik PE, Baram M, Vahid B. Does central venous pressure predict fluid responsiveness? A systematic review of the literature and the tale of seven mares. Chest 2008; 134: 172-178.

19. Cohn SM, Nathens AB, Moore FA, Rhee P, Puyana JC, Moore EE, Beilman G); StO2 in Trauma Patients Trial Investigators. Tissue oxygen saturation predicts the development of organ dysfunction during traumatic shock resuscitation. J Trauma 2007; 62: 44-54.

20. Sakamoto Y, Miyasho T, Kutsukata N, Ito T, Iwamura T, Nakashima A, Yahata M, Mashiko K, Yokota H, Obata T. Effectiveness of continuous venovenous hemodiafiltration using a polymethylmethacrylate membrane hemofilter judging from a multiplex suspension array system in septic shock patients. Crit Care 2011; 15 (Suppl 1): P118.
21. Honoré P. Newly adsorptive and high cut-off membranes? Ann Intensive Care 2011; $1: 24$.

22. Papadopoulos G, Sintou E, Siminelakis S, Koletsis E, Baikoussis NG, Apostolakis E. Perioperative infusion of low-dose of vasopressin for prevention and management of vasodilatory vasoplegic syndrome in patients undergoing coronary artery bypass grafting-A double-blind randomized study. J Cardiothorac Surg 2010; 5: 17.

23. Egi M, Bellomo R, Langenberg C, Haase M, Haase A, Doolan L, Matalanis G, Seevenayagam S, Buxton B. Selecting a vasopressor drug for vasoplegic shock after adult cardiac surgery: a systematic literature review. Ann Thorac Surg 2007; 83: 715-723.

24. Morelli A, Donati A, Ertmer C, Rehberg S, Kampmeier T, Orecchioni A, Di Russo A, D’Egidio A, Landoni G, Lombrano MR, Botticelli L, Valentini A, Zangrillo A, Pietropaoli P, Westphal M. Effects of vasopressinergic receptor agonists on sublingual microcirculation in norepinephrine-dependent septic shock. Crit Care 2011; 15 (Suppl 1): P91.

25. Vutskits L, Briner A, Klauser P, Gascon E, Dayer AG, Kiss JZ, Muller D, Licker MJ, Morel DR. Adverse effects of methylene blue on the central nervous system. Anesthesiology 2008; 108: 684-692.

26. Menardi AC, Viaro F, Vicente WV, Rodrigues AJ, Evora PR. Hemodynamic and vascular endothelium function studies in healthy pigs after intravenous bolus infusion of methylene blue. Arq Bras Cardiol 2006; 87: 525-532.

27. Dagenais F, Mathieu P. Rescue therapy with methylene blue in systemic inflammatory response syndrome after cardiac surgery. Can J Cardiol 2003; 19: 167-169.

28. Egea-Guerrero JJ, Martín-Bermúdez R, Miralles-Aguiar F, Revuelto-Rey J. Use of methylene blue in the treatment of vasoplegic syndrome after heart surgery: other perspectives on the case. Med Intensiva 2007; 31: 528.

29. Grayling M, Deakin CD. Methylene blue during cardiopulmonary bypass to treat refractory hypotension in septic endocarditis. J Thorac Cardiovasc Surg 2003; 125: 426-427.

30. Thielmann M, Marggraf G, Barnscheidt M, Massoudy P, Kamler M, Herold U, Piotrowski J, Jakob H. Methylene blue as therapeutic ultima ratio in patients with catecholamine-refractory vasoplegia after cardiopulmonary bypass surgery. Crit Care Med 2004; 32: A43.

31. Leone M, Bourgoin A, Cambon S, Dubuc M, Albanèse J, Martin C. Empirical antimicrobial therapy of septic shock patients: Adequacy and impact on the outcome. Crit Care Med 2003; 31: 462-467.

32. Aouifi A, Piriou V, Bastien O, Blanc P, Bouvier H, Evans R, Célard M, Vandenesch F, Rousson R, Lehot JJ. Usefulness of procalcitonin for diagnosis of infection in cardiac surgical patients. Crit Care Med 2000; 28: 3171-3176.

33. Wan S, Yim AP, Vincent JL. Inflammatory response to cardiopulmonary bypass. New Horiz 1999; 7: 462-471.

34. Tsuneyoshi I, Kanmura Y, Yoshimura N. Nitric oxide as a mediator of reduced arterial responsiveness in septic patients. Crit Care Med 1996; 24: 1083-1086.

35. Faraci FM, Heistad DD. Regulation of the cerebral circulation: role of endothelium and potassium channels. Physiol Rev 1998; 78: 53-97.

36. Sponholz C, Sakr Y, Reinhart K, Brunkhorst F. Diagnostic value and prognostic implications of serum procalcitonin after cardiac surgery: a systematic review of the literature. Crit Care 2006; 10: R145. 